\title{
Erratum to: "Structure and Properties of Nickel Ferrites Produced by Glow Discharge in the $\mathrm{Fe}^{2+}-\mathrm{Ni}^{2+}$ $\mathrm{SO}_{4}^{2-}-\mathrm{OH}^{-}$System" [Russian Journal of Applied Chemistry 87 (8), 1054- 1059 (2014)]
}

\author{
L. A. Frolova ${ }^{a}$, A. A. Pivovarov ${ }^{a}$, A. S. Baskevich ${ }^{b}$, and A. I. Kushnerev $a$ \\ a Ukrainian State University of Chemical Engineering, pr. Gagarina 8, Dnepropetrovsk, 49005 Ukraine \\ ${ }^{b}$ Dnepropetrovsk National University, ul. Nauki 13, Dnepropetrovsk, 320625 Ukraine \\ e-mail: frolova_l.a@mail.ru
}

Received December 9, 2014

DOI: $10.1134 / \mathrm{S} 1070427214100280$

In the title section of the article Frolov should be replaced by Frolova. 